\title{
Praktik Poligami Nabi Muhammad Saw dan Problematika Perkawinan Menyimpang
}

\author{
Elva Imeldatur Rohmah, Rinwanto, Dhika Prawhidhistia Wibowo \\ UIN Sunan Ampel Surabaya, Institut Agama Islam Nahdlatul Ulama Tuban \\ Email: Elva.imeldatur.rohmah@uinsby.ac.id, Rinwanto808@gmail.com, \\ nggendes@gmail.com
}

\begin{abstract}
Abstrak: Penelitian ini menjelaskan tentang praktik poligami Nabi Muhammad Saw dan problematika perkawinan menyimpang. Pada dasarnya, perkawinan dalam Islam merupakan akad yang sangat kuat atau mithaqan ghalizan untuk mentaati perintah Allah dan melaksanakannya merupakan ibadah. Dalam perkawinan terdapat pula poligami, sebagaimana yang dilakukan oleh Nabi Muhammad Saw yang sarat akan makna dan tujuan mulia. Namun pada kenyataannya, hakikat dan maknya suatu perkawinan semakin lama semakin menyimpang dan menjadi tradisi yang dianggap lumrah oleh masyarakat. poligami yang banyak dilakukan pada zaman sekarang yang sering digembor-gemborkan sebagai sunnah Nabi, ternyata telah menyimpang dari tujuan poligami itu sendiri. Kasus poligami yang ada pada zaman sekarang tidak sesuai dengan hakikat perkawinan poligami yang dilakukan oleh Nabi Muhammad dahulu. Jika Nabi melakukan poligami dengan tujuan melindungi para janda-janda tua yang lemah dan anak yatim. Sehingga pernikahan nabi tersebut lebih dilandaskan pada sisi kemanfaatan dan kemaslahatan, baik bagi umat maupun bagi wanita itu sendiri. Sedangkan kasus poligami yang banyak terjadi pada zaman sekarang kebanyakan dilandaskan pada kepentingan pemuasan nafsu seksual. Selanjutnya adanya fenomena perkawinan sesama jenis, seperti transgender, transeksual, gay, lesbian, dan biseksual, maupun perkawinan misyar merupakan bentuk deviasi sosial yang nyata terjadi dalam masyarakat. Perkawinan ini sangatlah jauh dari tujuan dan prinsip perkawinan sesungguhnya karena hanya ditujukan untuk pemenuhan nafsu biologis semata. Hal ini menyimpang dari nilai, ajaran, dan norma-norma yang ada dalam agama, masyarakat, dan hukum yang telah ada.
\end{abstract}

Kata Kunci: Poligami, Nabi Muhammad, perkawinan menyimpang.

\section{Pendahuluan}

Dalam Kompilasi Hukum Islam disebutkan bahwa yang dimaksud perkawinan dalam Islam adalah akad yang sangat kuat atau mithaqan 
ghalizan untuk mentaati perintah Allah dan melaksanakannya merupakan ibadah. ${ }^{1}$ Hal tersebut sesuai dengan Undang-Undang Perkawinan Nomor 1 Tahun 1974 yang menjelaskan bahwa perkawinan adalah ikatan lahir batin antara seorang pria dengan wanita sebagai suami istri dengan tujuan membentuk keluarga atau rumah tangga yang bahagia dan kekal berdasarkan ketuhanan Yang Maha Esa. ${ }^{2}$

Disyariatkannya perkawinan oleh Allah Swt tentu mempunyai target dan tujuan-tujuan tertentu yang akan dicapainya, di antaranya adalah :

1. Untuk mendekatkan diri (taqarrub) kepada Allah Swt.

2. Untuk mewujudkan kehidupan rumah tangga yang sakinah mawaddah wa rahmah.

3. Untuk memenuhi kebutuhan biologis (naluri seks) sekaligus memuliakan dan menjaga agar tidak tergelincir dalam perbuatan zina.

4. Melangsungkan keturunan, menurut naluri manusia mempunyai kecenderungan untuk mempunya keturunan yang sah. ${ }^{3}$

Dalam pernikahan, ada pula istilah poligami. Scara etimologis (lughawi) kata poligami berasal dari bahasa Yunani, yaitu gabungan dari dua kata: poli atau polus yang berarti banyak dan gamein atau gamos yang berarti perkawinan. Dengan demikian poligami berarti perkawinan yang banyak. ${ }^{4}$ Secara terminologis (ishthilahi) poligami adalah sistem perkawinan yang salah satu pihak memiliki atau mengawini beberapa lawan jenisnya dalam waktu yang bersamaan. ${ }^{5}$ Jika yang memiliki pasangan lebih dari satu itu seorang suami maka perkawinannya disebut poligini, ${ }^{6}$ sedang jika yang memiliki pasangan lebih dari satu itu seorang isteri maka perkawinannya disebut poliandri. Namun dalam bahasa sehari-hari istilah poligami lebih populer untuk menunjuk perkawinan seorang suami dengan lebih dari seorang isteri. Lawan dari poligami

\footnotetext{
${ }^{1}$ Abdurrahman, Kompilasi Hukum Islam Indonesia, (Surabaya : Kesindo Utama, 2010), hlm. 196.

${ }^{2}$ UU RI No. 1 Tahun 1974 tentang Perkawinan, (Jakarta : Wacana Intelektual, 2007), hlm. 22.

${ }^{3}$ Didi Junaidi Ismail, Membina Rumah Tangga Islam di Bawah Rida Illahi, (Bandung: Pustaka Setia, 2008), hlm. 73.

${ }^{4}$ Khairuddin Nasution, Riba \& Poligami: Sebuah Studi atas Pemikiran Muhammad Abduh, (Yogyakarta: Pustaka Pelajar, 1996), hlm. 84.

5 Tihami dan Sonari Sahrani, Fikih Munakahat, (Jakarta: PT. Raja Grafindo Persada, 2010), hlm. 351.

${ }^{6}$ Dalam beberapa tulisan ada yang menyebut poligami dengan istilah poligini. Kedua kata tersebut sebenarnya mempunyai kaitan erat dengan pernikahan lebih dari satu orang. Lihat Kamus Besar Bahasa Indonesia, edisi ke-2, (Jakarta: Balai Pustaka), hlm. 779
} 
adalah monogami, yakni sistem perkawinan yang hanya membolehkan seorang suami memiliki seorang isteri dalam satu waktu.

Tidak mudah memahami kenyataan "Nabi Saw mempraktikkan poligami" pada realitas kita dimana poligami menjadi sesuatu yang tidak sejalan dengan tuntutan keadilan perempuan. Banyak orang terperdaya dengan ungkapan "poligami itu sunnah", atau "poligami itu dipraktikkan Nabi". Ungkapan "poligami itu sunnah" pada praktiknya menafikan kenyataan sunnah-sunnah lain yang lebih memihak pada perkawinan monogami. Misalnya, kenyataan bahwa Nabi Muhammad Saw lebih lama hidup dengan satu isteri, yaitu Khadijah binti Khuwalid ra, pada saat dimana beliau masih muda belia dan hidup di masyarakat yang hampir semuanya mempraktikkan poligami. Di mata masyarakat Arab pada saat itu, seorang laki-laki seperti Nabi Muhammad Saw yang memiliki kedudukan dan ketokohan sangat wajar melakukan poligami, apalagi Khadijah ra sendiri jauh lebih tua dan tidak memberikan anak laki-laki. Tetapi Nabi Saw lebih memilih setia monogami sampai akhir hayat Khadijah ra. Ditambah empat tahun menduda setelah kematian Khadijah. Dalam kasus ini, dengan poligami sebagai sunah Rasul adalah poligami yang mengangkat harkat dan martabat perempuan dengan mengawini janda-janda perang, fakir miskin, dan dengan niatan untuk melindungi dan menyelamatkan anak-anak yatim. ${ }^{7}$

Pada hakikatnya perkawinan poligami yang dilakukan oleh Nabi Muhammad Saw sarat akan makna dan tujuan mulia. Namun tidak banyak orang yang mampu memahaminya, bahkan semakin lama makna hakikat suatu perkawinan semakin menyimpang dan menjadi tradisi yang dianggap lumrah oleh masyarakat. Oleh sebab itu, dalam penelitian ini akan dibahas mengenai praktik poligami yang dilakukan oleh Nabi Muhammad Saw dan problema perkawinan menyimpang.

\section{Poligami Sebelum Islam}

Jauh sebelum Islam lahir, poligami sudah dilakukan oleh hampir semua bangsa, baik Asia, Eropa, Afrika, maupun Amerika. Di Jazirah Arab sendiri, yang terkenal tidak suka melihat anak perempuan yang masih kecil, hingga berusaha membunuhnya, mereka berlomba-lomba mendapat perempuan dewasa dengan berbagai cara, melalui harta dan kekuasaan. Poligami telah dijalankan oleh bangsa-bangsa terdahulu sejak

7 Innayah Rohmaniyah, Menyoal Keadilan Dalam Poligami, (Yogyakarta: PWS UIN Sunan Kalijaga, 2009), hlm. 15. 
zaman primitif. Menurut sejarah, orang-orang besar dan ternama seperti raja Solomon, mempunyai tujuh ratus orang istri. Bahkan rekor fantastis dicapai oleh raja Uganda yang memiliki tujuh ribu istri. ${ }^{8}$

Dalam masyarakat tradisional Afrika, banyaknya jumlah istri merupakan kebanggaan tersendiri, lambang kesuksesan dan status sosial tinggi serta menandakan kesejahteraan hidup bagi mereka. Poligami merupakan adat warisan leluhur orang-orang Afrika, bukan saja dianggap sebagai kewajaran, melainkan juga sebagai kelembagaan. ${ }^{9}$ Kenyataan lain menunjukkan bahwa kebanyakan umat terdahulu, khususnya para pemeluk agama-agama sebelum Islam, membolehkan kawin tanpa batas yang jumlahnya, bahkan terkadang mencapai sepuluh orang wanita, seratus dan bahkan sampai ribuan istri tanpa syarat dan ikatan apapun. ${ }^{10}$ Maka setelah Islam datang, perkawinan lebih dari satu orang dibatasi dan diberlakukan syarat-syarat yang ketat. Kedatangan Islam membatasi jumlah wanita yang dapat dimiliki pria dalam berpoligami. Bagi laki-laki yang libido seksualnya berlebihan, Islam memberikan aturan-aturan agar tidak terjadi kesewenangan laki-laki terhadap wanita. Jadi, lahirnya syariat Islam ini adalah dalam upaya mengangkat derajat wanita, sebagaimana apa yang diharapkan dalam hakikat perkawinan itu sendiri.

Islam merupakan agama yang sesuai dengan fitrah manusia dan selalu terjun dalam suatu realita, mendidik dan menjauhkan manusia dari sikap buruk. Dengan menitikberatkan pada kepentingan manusia, baik secara individu maupun komunal (masyarakat), Islam membolehkan kawin lebih dari satu orang dengan batas maksimal empat orang istri. Kita menyaksikan betapa akut salah paham tentang poligami di tubuh Islam, karena yang salah memahami bukan hanya orang biasa atau orang awam, tapi juga figur-figur tertentu. Menurut Yusuf Qardhawi, salah satu penyebab salah paham poligami adalah gerakan penyesatan kaum orientalis dan Kristen keras terhadap orang-orang Islam. Mereka menggembor-gemborkan poligami seolah merupakan inti ajaran Islam bahkan suatu yang hampir wajib. Sebagian kalangan mengesankan seolah Islam adalah yang pertama kali mensyariatkan poligami. Ini menurut Yusuf Qardhawi sama sekali tidak benar. Sesungguhnya banyak umat dan agama sebelum Islam yang membolehkan poligami bahkan dengan

\footnotetext{
${ }^{8}$ Nasiri, Praktik Prostitusi Gigolo ala Yusus al-Qardawi, (Surabaya: Khalista, 2010), hlm. 50.

${ }^{9}$ Nasiri, hlm. 50.

${ }^{10}$ Nasiri, hlm. 50-51.
} 
berpuluh-puluh wanita atau lebih, tanpa ada pembatasan jumlah istri. Islam datang justru untuk membatasi poligami yang ketika itu sangat lumrah. Makanya ketika Ghailan bin Salamah masuk Islam dan ia memiliki 10 istri, maka Nabi Muhammad Saw bersabda kepadanya, "Pilihlah dari 10 itu 4 istri dan ceraikan sisanya". Demikian juga berlaku bagi yang masuk Islam yang istrinya 8 atau 6 orang, maka Nabi memerintahkan kepadanya untuk memilih 4 saja. ${ }^{11}$

\section{Poligami dalam Perspektif Kaum Feminis}

Undang-undang nomor 1 tahun 1974 dan Kompilasi Hukum Islam (KHI) yang semula ditujukan untuk melindungi perempuan, ternyata dalam kenyataannya justru merugikan perempuan. Dalam UU no 1 tahun 1974 pasal 3 ayat (1) disebutkan secara implisit bahwa asas perkawinan adalah monogami, tetapi pada ayat (2) memberikan kelonggaran kepada suami untuk berpoligami hingga sebatas 4 orang istri. Disini Musdah Mulia berpendapat adanya ambivalensi hukum atau standar ganda. ${ }^{12}$

Syarat-syarat diperbolehkannya poligami dalam aturan hukum di Indonesia, seolah-olah mengamini bahwa tujuan perkawinan yang utama adalah persoalan "biologis". Lihat saja dalam klausul-klausul yang membolehkan suami menikah lagi, yaitu apabila istri tidak mampu memberikan keturunan anak dan cacat. Belum lagi Pengadilan yang sering mempertanyakan istri, apakah alasan penolakan mereka terhadap poligami suami layak atau tidak. Jika tidak memenuhi kewajibannya sebagai istri (mengurus rumah tangga, punya anak, nusyuz), perempuan ditempatkan sebagai pihak yang salah dan demikian memberikan alasan bagi suami untuk poligami. Tujuan perkawinan semata-mata diarahkan untuk pemenuhan kepentingan biologis dan meneruskan keturunan, dengan asumsi, bahwa perempuan selalu siap sedia untuk memenuhi dan kalau tidak, akan menjadi alasan bagi suami untuk menikah lagi dengan perempuan lain. ${ }^{13}$

Jika yang dipermasalahkan adalah kewajiban, dan ketika salah satu di antara suami atau istri tidak dapat melaksanakan kewajibannya,

11 Anshori Fahmi, Siapa Bilang Poligami itu Sunnah?, (Bandung: Pustaka IIMaN, 2007), hlm. 173-174.

12 Siti Musdah Mulia dan Anik Farida, Poligami : Budaya Bisu Yang Merendahkan Martabat Perempuan, (Yogyakarta: Kibar Press, 2007), hlm. 65-66.

${ }^{13}$ Siti Syamsiatun dan Alimatul Qibtiyah, Amandemen Undang-Undang Perkawinan Sebagai Upaya perlindungan Hak Perempuan dan Anak, (Yogyakarta: PSW UIN Sunan Kalijaga, 2006), hlm. 56. 
seharusnya yang satu menolongnya, bukan hanya mempertimbangkan kewajiban dan mengabaikan haknya. Jika salah satunya mendapat cacat badan atau menderita penyakit yang tidak bisa disembuhkan, yang satunya juga merasakan kecacatan dan kesakitan itu, bukan justru berpoligami.

Jika selama hidup berumah tangga tidak kunjung mendapatkan keturunan, tidak berarti salah satunya bertanggung jawab sedangkan yang lainnya tidak. Ironisnya, jika istri tidak kunjung hamil, maka banyak kasus yang disuruh berobat adalah istri, dan istri dianggap infertille. Hal ini juga dijadikan alasan kuat suami untuk menikah lagi. Namun ketika suami yang infertille, maka istri tidak didukung untuk menceraikan suaminya dengan alasan suaminya tidak mampu memberikan keturunan. Istri justru diharapkan, bahkan diwajibkan untuk menunjukkan loyalitasnya kepada suaminya dengan menjadi istri yang tidak mempermasalahkan tentang anak, dan hal semacam ini mendapatkan legitimasi dari masyarakat.

Jika Rasulullah mengutamakan misi pernikahan adalah "regenerasi" dan mempermasalahkan hal tersebut, tentunya Rasul sudah menikahi perempuan lain ketika masih bersama Khadijah agar bisa mendapatkan anak laki-laki, untuk membantu dakwah beliau dalam mengembangkan Islam. Sementara poligami yang digembor-gemborkan selalu diinisiasi dari sunnah Rasulullah. Jika berdasarkan frame tersebut, apakah izin poligami karena istri tidak dapat melahirkan tetap dijadikan alasan untuk melegalkan poligami suami di mata hukum. Oleh karena itu, aturan tersebut perlu ditinjau kembali agar benar-benar mengamalkan syari'at sesuai dengan ajaran al-Qur'an dan sunnah. ${ }^{14}$

Begitu juga terhadap pandangan, bahwa laki-laki mempunyai potensi yang lebih besar untuk melakukan hubungan seks dibanding wanita, karena secara umum wanita pasti melalui fase haid di tiap bulannya, maka dengan alasan ini jalan keluarnya adalah dengan menikahi wanita lebih dari satu. Asghar Ali Engineer tokoh feminis berkebangsaan India ini membantah argumen tersebut. Asghar menyatakan, ayat al-Qur'an dan hadis tidak pernah memberikan alasan dan petunjuk kebolehan poligami karena alasan seks. Alasan yang ada adalah menyantuni anak

14 Beni Ahmad Syaebani, Perkawinan Hukum Islam \& Undang-Undang : Perspektif Fikih Munakahat \& Undang-Undang No. 1 tahun 1974 Tentang Poligami dan Problematikanya, (Bandung: Pustaka Setia, 2008), hlm. 32. 
yatim dan janda. ${ }^{15}$ Harus diingat bahwa perkawinan pra Islam tidak ada batasan, sedangkan dalam Islam ada batasan hingga empat, yakni pengurangan secara drastis, sebuah reformasi yang luar biasa. Demikian juga poligami yang dilakukan Nabi Muhammad Saw dilakukan kepada para janda yang dilakukan setelah 4 tahun kematian Khadijah. Maka kebolehan poligami hanya dalam keadaan-keadaan tertentu yang sangat sulit.

\section{Pernikahan dan Poligami Nabi Muhammad Saw}

Salah satu tuduhan keji yang sering dilontarkan oleh kaum orientalis dan nasrani adalah terkait pernikahan Nabi Muhammad dan poligami beliau. Mereka menganggap bahwa Nabi Muhammad melakukan poligami untuk kesenangan semat-mata bahkan lebih keji lagi mereka menuduh bahwa Nabi Muhammad itu hiperseks dan budak nafsu syahwat. Padahal sesungguhnya terdapat rahasia agung dibalik poligami yang dilakukan Nabi tersebut. Berikut ini adalah pembahasan tentang pernikahan dan poligami yang dilakukan oleh Nabi Muhammad Saw.

1. Khadijah binti Khuwailid

Khadijah binti Khuwailid adalah seorang janda dari bani Asad, yang berprofesi sebagai pedagang yang kaya dan dihormati, ia biasa mengupah orang Quraisy untuk memperdagangkan hartanya. Mendengar tentang sifat-sifat Nabi Muhammad Saw, Khadijah pun menawari beliau, dan sejak saat itu Nabi memperdagangkan harta Khadijah ke Syiria (Syam). Dengan kejujuran dan kemampuannya ternyata beliau mampu memperdagangkan barang-barang Khadijah dengan baik, dengan cara perdagangan yang lebih banyak menguntungkan daripada yang dilakukan orang lain sebelumnya. Pada saat beliau berumur 25 tahun, setelah perjalanan dagang ini Khadijah menawari Nabi Muhammad untuk menikah dengannya. Beberapa pemuka Quraisy pernah melamarnya, tetapi ditolaknya. la yakin mereka itu melamar hanya karena memandang hartanya. ${ }^{16}$ Dan beliau menerima tawaran tersebut. ${ }^{17}$

Hingga mencapai usia 50 tahun, Siti khadijah merupakan istri beliau satu-satunya, artinya selama 25 tahun Rasulullah Saw

15 Asghar Ali Engineer, Hak-hak Perempuan Dalam Islam, alih bahasa Farid Wajidi dan Cici Farika Assegaf, (Yogyakarta: LSPPA 7 CUSO, 1994), hlm. 224.

${ }^{16}$ Afzalur Rahman, Ensiklopedi Nabi Muhammad Saw : Muhammad Sebagai Suami dan Ayah, (Bandung: Pelangi Mizan, 2009), hlm. 33.

17 Afzalur Rahman, hlm. 34-35. 
menghayati sebagian besar masa mudanya dengan hidup bersama seorang istri saja yakni Khadijah binti Khuwalid. ${ }^{18}$

2. Aisyah binti Abu Bakar Ash-Shiddiq

Setelah Khadijah wafat tidak lama kemudian menyusul Abu Thalib, paman beliau wafat. Padahal dialah seorang yang melindungi Nabi Muhammad Saw dari gangguan kaum musyrikin. Keadaan ini membuat sedih hati Rasulullah Saw, melihat hal itu sahabat Abu Bakar meminta agar beliau mau menikah dengan anaknya yang bernama Siti Aisyah. Karna kecintaan beliau pada sahabatnya yang paling setia ini, akhirnya Rasulullah menyetujui permintaannya, dan akhirnya menikahi Siti Aisyah pada tahun kesepuluh kenabian. ${ }^{19}$

3. Siti Saudah binti Zam'ah

Ia adalah seorang Janda yang berbadan gemuk dan sudah tua bahkan mendekati menopause, suaminya adalah Sakran bin Amr yang gugur dalam medan perang, sehingga Siti Saudah kehilangan seorang pelindung yang menjamin kehidupannya sehari hari, hal ini mendorong Nabi Muhammad Saw untuk menikahinya karna rasa kemanusiaan dan pernghargaan terhadap suaminya yang gugur membela agama Islam. Karena usianya sudah tua, Siti Saudah menyerahkan gilirannya kepada siti Aisyah. ${ }^{20}$

4. Ummu Salamah

Nama aslinya Hindun binti Umayyah bin al-Mughirah, sebelum menjadi istri Rasulullah Saw ia adalah istri Salamah bin Abdul 'Asad Al-Makhzumiy yang meninggal dalam perang Uhud. Saat Rasulullah meminangnya, ia berkata "aku ini adalah seorang wanita yang sudah tua, mempunyai banyak anak dan mudah cemburu". Mendengar jawaban ini Rasulullah menjawab: "Jika engkau berumur, maka aku lebih tua darimu, soal minder biarlah Allah yang menghilangkannya dari dirimu, adapun masalah tanggungan keluarga (anak-anak) serahkan kepada Allah dan Rasulnya".21

5. Ramlah binti Abu Sufyan

Ramlah binti Abu Sufyan meninggalkan orang tuanya untuk hijrah ke Habasyah (Etiopia) bersama suaminya. Tapi kemudian

\footnotetext{
${ }^{18}$ Afzalur Rahman, Ensiklopedi Nabi Muhammad Saw, hlm. 44

${ }^{19}$ Afzalur Rahman, hlm. 45.

20 Afzalur Rahman, hlm. 46.

${ }^{21}$ Afzalur Rahman, hlm. 63-64.
} 
suaminya memeluk agama Nasrani disana dan menceraikannya, sehingga ia hidup sendiri di perantauan. Maka melalui Negus, penguasa Etiopia, Nabi Saw melamarnya dengan harapan mengangkatnya dari jurang penderitaan, sekaligus menjalin hubungan dengan ayahnya yang ketika itu merupakan salah satu tokoh utama kaum musyrikin di Makkah. ${ }^{22}$

6. Huriyah binti Al-Harits

Menurut Ibnu Ishaq, seorang dari sejarawan awal muslim, pada tahun ke $6 \mathrm{H}$ terjadi peperangan antara kaum Muslim dengan kaun Yahudi Bani Mushthaliq. Suami Huriyah tewas dalam peperangan tersebut, akibat peperangan ini, sebagaimana hukum peperangan yang berlaku saat itu, mereka yang kalah menjadi tawanan dan budak bagi pemenang. Di antara mereka yang tertawan adalah Huriyah binti al-Harits, seorang putri dari al-Harits bin Abi Dlorror pemimpin Bani Mushthaliq. Sebagai putri seorang terpandang Huriyah tidak rela dirinya dijadikan budak, maka ia berniat menebus kepada Tsabit bin Qais yang kebetulan saat pembagian harta rampasan mendapat dirinya. Karena tidak memiliki harta lagi, maka ia pergi menghadap Rasulullah agar dibantu melunasi tebusan tersebut. Rasulullah yang telah mengajarkan kepada para sahabatnya agar mendidik budak dan kalau bisa memerdekakan dan menikahinya, Rasulullah memberikan contoh dengan memerdekakan Huriyah dan menawarkan pinangannya, ternyata Huriyah mengiyakan. Dengan persetujuan Huriyah ini maka Rasulullah menikahinya, dan dengan pernikahan tersebut para sahabat mengembalikan harta rampasan perang, sekaligus memerdekakan \pm 100 keluarga. ${ }^{23}$

7. Siti Khafsah binti Umar bin Khatta

Ia adalah putri Umar bin Khattab, yang menjadi janda setelah suaminya wafat akibat luka parah yang dideritanya saat perang badar. Pada mulanya Umar bin Khattab meminta kepada Abu Bakar Ash-Siddiq untuk bersedia menikahi putrinya yang sudah menjanda itu, akan tetapi dengan iba hati Abu Bakar tidak dapat memenuhi keinginan Umar. Kemudian Umar meminta kepada Usman bin Affan

22 Anshori Fahmi, Siapa Bilang Poligami itu Sunnah?, hlm. 187

${ }^{23}$ Anshori Fahmi, hlm. 187. 
untuk menikahi putrinya, tetapi Utsman juga tidak dapat memenuhi keinginan Umar. Di kalangan masyarakat Arab pada masa itu, mempunyai seorang anak perempuan terlambat nikah atau menjadi janda dalam waktu lama dipandang sebagai hal yang memalukan dan menghawatirkan, betapa resah perasaan Umar menghadapi kenyataan pahit itu. Kemudian Umar mengadu kepada Rasulullah, dan beliau menjawab: "Hafshah akan menikah dengan yang lebih baik dari Utsman, dan Utsman akan menikah dengan yang lebih baik dari Hafshah". Umar tidak pernah menyangka bahwa Rasulullah akan menikahi putrinya, hingga ia bersorak kegirangan mengumumkan kepada para sahabatnya, yang kemudian disambut oleh Abu Bakar juga Utsman. Dan seperti dikatakan oleh Nabi, maka Utsman akhirnya menikah dengan putri beliau Umi Kultsum. ${ }^{24}$

8. Shafiyah binti Huyaiy

Shafiyah binti Huyaiy adalah putri pemimpin Yahudi dari Bani Quraidhah yang ditawan setelah kekalahan mereka dalam pengepungan yang dilakukan Nabi Saw. Ia diberi pilihan kembali kepada keluarganya atau tinggal bersama Nabi Saw dalam keadaan bebas merdeka. Ia memilih untuk tinggal bersama Nabi. Di rumah itu, Shafiyah hidup terhormat sampai suatu ketika Nabi Saw mendengar ada seseorang yang memakinya bertubuh pendek. Nabi Saw menghibur Shafiyah sambil mengecam dengan keras pemakinya. ${ }^{25}$

9. Zainab binti Jahsy

Zainab binti Jahsy adalah sepupu Nabi Muhammad Saw, ia dinikahkan langsung oleh Nabi Saw dengan bekas anak angkat dan budak beliau Zaid bin Haritsah. Rumah tangga mereka tidak bahagia, sehingga mereka bercerai dan sebagai penanggung jawab pernikahan itu Nabi Muhammad Saw menikahinya atas perintah Allah Swt, sekaligus untuk membatalkan adat jahiliyah yang menganggap anak angkat sebagai anak kandung, sehingga ayah anak angkatnya tidak boleh menikahi bekas istri anak angkatnya itu. (QS. Al-Ahzab ayat 3637). ${ }^{26}$

${ }^{24}$ Afzalur Rahman, Ensiklopedi Nabi Muhammad Saw, hlm. 59-60.

${ }^{25}$ Anshori Fahmi, Siapa Bilang Poligami itu Sunnah?, hlm. 188.

${ }^{26}$ Anshori Fahmi, Siapa Bilang Poligami itu Sunnah?, hlm. 188. 
10. Zainab binti Khuzaimah

Ia adalah seorang janda. Ia pernah menikah dengan Abdullah bin Jahsy yang meninggal saat perang Uhud. Pada saat itu tidak seorang pun kaum muslimin yang berminat menikahinya, maka Nabi Muhammad Saw pun menikahinya. Dalam kaum muslimin Zainab binti Khuzaimah dikenal dengan sebutan (Ummul Masakin) karna kedekatannya dengan orang orang miskin. ${ }^{27}$

Itulah istri-istri Nabi Muhammad Saw yang keseluruhannya janda ${ }^{28}$, kecuali Aisyah yang beliau nikahi setelah bermonogami hingga usia 50 tahun lebih. Jika dilihat dari seluruh pernikahan nabi seperti yang telah kita bahas, maka pernikahan nabi tersebut agaknya lebih dilandaskan pada sisi kemanfaatan dan kemaslahatan, baik bagi umat maupun bagi wanita itu sendiri. Hal ini sekaligus menampik tuduhan bahwa perkawinan Rasulullah dilandaskan pada kepentingan pemuasan seksual.

\section{Macam-macam Perkawinan Menyimpang;}

a. Perkawinan Transgender

Transgender adalah istilah yang digunakan untuk mendeskripsikan orang yang melakukan, merasa, berpikir atau terlihat berbeda dari jenis kelamin yang ditetapkan saat mereka lahir ${ }^{29}$. Selain kasus transgender atau transeksual juga terdapat kasus kebingungan jenis kelamin dari orang yang memiliki kelainan atau cacat bawaan karena memiliki dua alat kelamin yaitu kelamin laki-laki dan perempuan ${ }^{30}$. Orang berkelamin ganda yang tidak jelas apakah status kelaminnya, membuat mereka merasa berbeda dengan yang lainnya dan mereka menganggap dirinya tidak normal dan berbeda dengan yang lainnya.

Kaum transgender memiliki suatu ketidakpuasan terhadap dirinya sendiri karena merasa tidak adanya kecocokan antara bentuk fisik dan kelamin dengan kejiwaan. Ekspresi orang yang mengalami kebingungan jenis kelamin ini bisa terlihat dalam bentuk dandanan, gaya bicara, tingkah laku, bahkan sampai kepada keinginan untuk

\footnotetext{
27 Afzalur Rahman, Ensiklopedi Nabi Muhammad Saw, hlm. 63

28 Semua istri Nabi Muhammad Saw (selain Aisyah) adalah janda-janda yang berusia di atas 45 tahun.

${ }^{29}$ Transeksual dan Transgender, http://psikologi4u.blogspot.com/2008/08/transeksualdan transgender

30 Fenomena Transgender dan Hukum Operasi Kelamin, http://mdakwatuna.com/fenomena transgender-dan-hukum-operasi-kelamin/
} 
melakukan operasi pergantian kelamin (Sex Reassignment Surgery). Menurut dr. Dadi Garnadi operasi pergantian kelamin tidak bisa dilakukan oleh sembarang orang dengan mudah. Untuk dapat dilakukan operasi perubahan kelamin sesuai standar IDI harus didahului oleh observasi oleh Tim Dokter yang meliputi tes psikologi, tes hormonal, tes kepribadian, tes kesehatan yang dilakukan oleh ahliahli seperti Psikiater, Psikolog, Bedah, Penyakit Dalam, Genetikal, Obstetry dan Ginecology, setelah melalui serangkaian tes barulah seseorang dapat melakukan operasi perubahan. Operasi kelamin bisa digolongkan termasuk dalam operasi bedah plastik dan rekonstruksi organ tubuh. Menurut Undang-Undang Republik Indonesia Nomor 23 Tahun 1992 Tentang Kesehatan Pasal 37 ayat (2) bedah plastik dan rekonstruksi tidak boleh bertentangan dengan norma yang berlaku dalam masyarakat ${ }^{31}$. Norma yang dimaksud dalam penjelasan Undang-Undang Republik Indonesia Nomor 23 Tahun 1992 Tentang kesehatan Pasal 37 ayat (2) adalah norma hukum, agama, kesusilaan dan kesopanan, sedangkan dalam norma hukum tidak ada aturan mengenai transgender ${ }^{32}$.

Hal ini mengakibatkan munculnya kekuatan baru yang sangat menakutkan karena semakin banyaknya kaum transgender. Selain kaum transgender, ada pula kaum serupa yakni kaum gay, lesbian, dan biseksual. Seperti air bah yang melanda seluruh daratan Eropa dan Amerika. GLBT (kaum gay, lesbian, biseksual, dan transgender) benar-benar menjadi "trend" baru di seantero jagad.

Di Amerika Serikat berdasarkan Gallup Poll, di mana rakyat Amerika Serikat 50,7 persen mendukung perkawinan sejenis. Perkawinan sejenis sudah menjadi pilihan dan keyakinan. Para pemimpin partai politik lumpuh, para pastur lumpuh, para uskup lumpuh, dan para rabbi lumpuh. Mereka hanya bisa mengamini kecenderungan masyarakat Barat. Gereja dan Synagog tidak lagi memiliki peranan apapun dalam kehidupan. Belakangan para pendeta, pastur dan rabbi, mereka sibuk memberkahi pernikahan

31 Undang-Undang Kesehatan dan Praktik Kedokteran, (Yogyakarta: Best Publisher, 2009), hlm. 22.

32 Undang-Undang Kesehatan dan Praktik Kedokteran, hlm. 75. 
sesama jenis. Para rohaniawan tidak mampu lagi bersikap menolak menghadapi perubahan masyarakat Barat yang sangat ekstrim itu.

Gerakan GLBT sekarang sudah menjadi sebuah pilihan hidup dikalangan masyarakat Barat. GLBT sudah bukan sesuatu yang tabu dan memalukan. Inilah sebuah penyimpangan secara kodrati, tetapi menjadi pilihan hidup. Pilihan hidup masyarakat Barat yang cenderung kepada GLBT itu sangat menentukan masa depan kehidupan mereka ${ }^{33}$. Dunia bergerak menuju pilihan dan kecenderungan yang akan menghancurkan kehidupan mereka sendiri. Mereka melakukan pilihan yang sangat naif, dan ini hanya mengulangi sejarah kelam di masa lalu, di masa Nabi Luth, yang mempraktekkan kehidupan yang dibenci serta melanggar fitrah. Gerakan GLBT ini juga bisa dikatakan sangat menyimpang karena tidak sesuai dengan nilai-nilai dan kondisi nyata kehidupan di masyarakat. Tingkat perbedaannya juga sangat nampak dalam masalah ini karena jelas-jelas menyalahi norma yang telah ada.

Namun jika kasus transgender ini dilihat dari perspektif lain, memang tidak ada seorang pun yang menghendaki adanya kelainan atau kebingungan alat kelamin terjadi pada dirinya. Hal ini terjadi secara alami tanpa dibuat-buat. Namun ketika masalah ini dihadapkan pada suatu yang sakral dan tinggi maknanya seperti pernikahan, akan sangat dianggap menyimpang jika seorang melakukan perkawinan sejenis, meskipun secara kasat mata orang tersebut sudah berubah dari jenis kelamin asalnya.

Perkawinan memiliki beberapa tujuan mulia, diantaranya melanjutkan keturunan. Sedangkan jika perkawinan dilakukan oleh pasangan yang sejenis (pria dengan pria, wanita dengan wanita), maka mustahil tujuan ini dapat terpenuhi, yang ada hanyalah pemuasan hasrat dan nafsu belaka. Apalagi dalam Islam sangat mengutuk perbuatan laki-laki yang menyerupai perempuan, dan perempuan yang menyerupai laki-laki. Dalam norma kesusilaan dan kesopanan, masalah transgender atau kebingungan jenis kelamin masih dianggap sesuatu yang aneh dan selalu mendapat cemooh dan hinaan dari masyarakat.

33 Bangkitnya Gerakan Gay, Lesbian, Biseksual, dan Transgender Dunia, http://www .globalmuslim.web.id/2012/05/bangkitnya-gerakan-gay-lesbian.html 
b. Perkawinan Misyar

Kawin misyar adalah model perkawinan yang muncul pertama kali di Mesir, kemudian berkembang pesat di kalangan masyarakat Timur Tengah. Kawin misyar ini pertama kali dibahas oleh Yusuf alQardhawi dalam kitabnya yang berjudul Zawaj al-Misyar Haqiqatuh wa Hukmuh. Al-Qardhawi menjelaskan bahwa definisi yang tepat untuk kawin misyar ini tidak ada, tetapi setelah dilihat secara kebahasaan maka ia menyimpulkan bahwa kawin misyar adalah perkawinan yang dilakukan oleh wanita karir yang kaya raya yang tidak sempat memikirkan untuk kawin (ia melebihi usia sempurna untuk melakukan perkawinan) mencari laki-laki ganteng dan gagah yang bersedia kawin dengan dirinya dan si laki-laki tersebut tidak dikenakan membayar nafkah, menyediakan tempat tinggal, dan sebagainya, bahkan tidak wajib tinggal serumah. Pihak laki-laki hanya berkewajiban untuk memuaskan si perempuan dan setelah itu bisa pulang ke rumahnya sendiri, tetapi jika di kemudian hari si wanita itu membutuhkan dia, maka dia harus datang sesuai permintaan dari si wanita tersebut. Dengan demikian, praktik nikah seperti ini tidaklah berbeda dengan praktik "gigolo", dimana seorang wanita kaya mencari laki-laki (bahkan mau membayar mahal kepada dia) yang mau melayani dan memenuhi hasrat biologis wanita tersebut ${ }^{34}$.

Yusuf al-Qardhawi mengakui bahwa model perkawinan seperti bukanlah tipe perkawinan yang dianjurkan dalam Islam, tetapi diperbolehkan karena adanya desakan, imbas dan perkembangan masyarakat, dan karena perubahan zaman, dengan catatan akad nikahnya harus dilaksanakan, karena jika tidak maka nikahnya batal. Dengan demikian, kawin misyar menurutnya tidak diharamkan, karena tujuannya untuk menghormati dan mensucikan wanita, dan juga mempertimbangkan kemaslahatan dan kerugiannya, manfaat, dan madharatnya ${ }^{35}$.

Alasan lain Yusuf al-Qardhawi memperbolehkan perkawinan ini karena ia menganggap bahwa pada zaman sekarang, rintangan perkawinan sangatlah beragam, yang sebagian besar muncul dari wanita itu sendiri. Dari sini kemudian muncullah kaum awanis, yaitu;

34 Nasiri, Praktik Prostitusi Gigolo ala Yusus al-Qardawi, hlm. 48-49.

35 Nasiri, hlm. 135. 
1) Wanita-wanita yang melajang sampai tua, yang telah melewati masa untuk melaksanakan perkawinan.

2) Wanita-wanita yang masih hidup dengan orang tua mereka, dan tidak mampu memenuhi kebutuhan fitrah dalam membangun sebuah keluarga dan menjadi seorang ibu.

3) Wanita-wanita yang mengalami perceraian, fenomena ini sangatlah banyak sekali.

4) Janda yng ditinggal mati oleh suaminya sendirian atau bersama harta yang melimpah ruah.

5) Wanita-wanita karier, berkarya dan bekerja sendiri seperti menjadi guru, instruktur, dokter, pengacara, atau profesi lainnya yang berpenghasilan tetap.

Dengan adanya kaum awanis tersebut di atas, maka mereka semuanya tidak menuntut hak materi dari suaminya ${ }^{36}$. Dari alasan Yusuf al-Qardhawi di atas dapat diketahui bahwa tujuan perkawinan misyar hanya mengarah pada pemenuhan kenutuhan biologis para wanita yang secara usia dan materi sudah mapan. Di bawah ini adalah beberapa kemiripan antara kawin misyar dengan praktik sewa gigolo :

a. Baik perkawinan misyar atau praktik sewa gigolo sama-sama mencari laki-laki yang tampan, gagah, dan fisiknya yang sehat.

b. Sama-sama dilakukan secara sembunyi-sembunyi.

c. Sama-sama dilakukan untuk pemenuhan nafsu biologis wanita.

d. Sama-sama dibiayai oleh wanita.

e. Sama-sama tidak ingin punya keturunan dari hubungan tersebut.

f. Sama-sama tidak tinggal satu rumah.

g. Sama-sama memberikan keuntungan bagi pihak laki-laki, karena jika dia bisa memuaskan wanita tersebut, maka dia mendapatkanbonus atau biaya hidup plus uang saku dari pihak wanita.

h. Sama-sama dikendalikan oleh pihak wanita. Artinya, baik kawin misyar maupun praktik gigolo, mengenai waktu, tempat, dan lainnya dalam berhubungan sama-sama ditentukan oleh pihak wanita.

i. Sama-sama tidak dicatatkan di Kantor Urusan Agama (KUA) setempat.

${ }^{36}$ Nasiri, Praktik Prostitusi Gigolo ala Yusus al-Qardawi, hlm. 137-138. 
j. Sama-sama tidak boleh diketahui oleh pihak keluarga laki-laki maupun wanita.

k. Sama-sama hukumnya haram dan tidak boleh dilakukan.

Secara garis besar tujuan dalam perkawinan misyar menurut penulis tidak seperti tujuan perkawinan dalam Islam. Yang mana tujuannya bukan untuk menjalin hubungan kekeluargaan dan membina keluarga, tetapi murni hanya hubungan seksual dan ini termasuk dalam kategori perkawinan yang tidak murni dan hukumnya haram. Selain itu, perkawinan ini tidak mampu mewujudkan cita-cita perkawinan yakni membangun keluarga sakinah mawaddah warahmah. Karena suami hanya menggaulinya sebentar, sebulan sekali atau dua kali, kemudian suami pergi untuk menikmati hidupnya dengan wanita lain. Atau dia hanya menggunakan wanita (istri) tersebut untuk tujuan tidak mempunyai keturunan sehingga tidak ada unsur tanggung jawab, dan sebenarnya dalam hal ini telah terjadi penyimpangan dari maksud Allah dalam mensyariatkan perkawinan.

Dari sini bisa disimpulkan bahwa kawin misyar yang difatwakan Yusuf al-Qardhawi lebih mengarah pada pemenuhan nafsu seksual belaka, dan lebih banyak mendatangkan madharat dari pada maslahat. Di sisi lain, parktik kawin misyar akan dikecam masyarakat umum karena praktik nikah ini mirip dengan praktik sewa gigolo. Artinya parktik kawin misyar jelas lebih banyak bahayanyadan akan memunculkan fitnah yang lebih besar di tengah-tengah masyarakat. Sehingga praktik kawin misyar ini lebih baik ditinggalkan karena hanya akan mendatangkan kerusakan.

\section{Kritik Terhadap Praktik Poligami dan Pernikahan Menyimpang}

Perkawinan merupakan tujuan syariat yang dibawa Rasulullah Saw, yaitu penataan hal ihwal manusia dalam kehidupan duniawi maupun ukhrowi. Dengan pengamatan sepintas pada batang tubuh ajaran fikih, dapat dilihat adanya empat garis penataan itu yakni :

1. Rubb al-Ibadat, yang menata hubungan manusia selaku makhluk dengan penciptanya.

2. Rubb al-Muamalat, yang menata hubungan manusia dalam lalu lintas pergaulannya dengan sesamanya untuk memenuhi hajat hidupnya sehari-hari. 
3. Rubb al-Munakahat, yang menata hubungan manusia dalam lingkungan keluarga.

4. Rubb al-Jinayat, yang menata pengamanannya dalam suatu tertib pergaulan yang menjamin ketentramannya ${ }^{37}$.

Di dalam Islam terdapat pula beberapa prinsip perkawinan, antara lain:

a) Memenuhi dan melaksanakan perintah agama bahwa perkawinan adalah sunnah Nabi, itu berarti bahwa melaksanakan perkawinan itu pada hakikatnya merupakan ajaran dari agama yang mengatur perkawinan itu, memberi batasan rukun dan syarat yang perlu. Apabila rukun dan syarat itu tidak terpenuhi, maka batal atau fasid perkawinannya ${ }^{38}$.

b) Kerelaan dan persetujuan sebagai salah satu syarat yang harus dipenuhi oleh pihak yang hendak melaksanakan perkawinan adalah ikhtiyar (tidak ada paksaan) pihak yang melangsungkan perkawinan itu dirumuskan dengan kata-kata kerelaan calon istri dan suami atau persetujuan mereka. Prinsip hakiki dari suatu perkawinan adalah adanya kerelaan dari kedua calon suami istri ${ }^{39}$.

c) Perkawinan mempunyai tujuan di antaranya untuk dapat berketurunan dan untuk ketenangan, ketentraman, cinta, dan kasih sayang. Kesemuanya ini ini dapat dicapai hanya dengan prinsip bahwa perkawinan adalah untuk selamanya, bukan hanya dalam waktu tertentu saja ${ }^{40}$.

Berdasarkan prinsip perkawinan di atas, maka poligami yang banyak dilakukan pada zaman sekarang yang sering digembor-gemborkan sebagai sunnah dan ajaran Nabi, pada hakikatnya telah menyimpang dari tujuan poligami itu sendiri. Kasus poligami yang ada pada zaman sekarang tidak sesuai dengan hakikat perkawinan poligami yang dilakukan oleh Nabi Muhammad dahulu. Jika Nabi melakukan poligami dengan tujuan melindungi para janda-janda tua yang lemah dan anak yatim. Yang mana pernikahan nabi tersebut lebih dilandaskan pada sisi kemanfaatan dan kemaslahatan, baik bagi umat maupun bagi wanita itu sendiri. Sedangkan kasus poligami yang banyak terjadi pada zaman sekarang kebanyakan dilandaskan pada kepentingan pemuasan nafsu

\footnotetext{
${ }^{37}$ Ali Yafie, Pandangan Islam Terhadap Kependudukan dan Keluarga Berencana, (Jakarta: Lembaga Kemaslahatan Keluarga Nadhatul Ulama dan BKKBN, 1982), hlm. 1.

38 Abu Shuja', al-Iqna', (Surabaya: al-Hidayah, tt), hlm. 119.

${ }^{39}$ Abu Shuja', hlm. 120.

${ }^{40}$ Wahbah al-Zuhaili, al-Fiqh al-Islami wa Adillatuh, (Beirut: Dar al-Kutub, 1999), hlm. 50.
} 
seksual. Bahkan berpoligami merupakan suatu kebanggaan tersendiri bagi seorang pria. Ia dianggap gagah jika memiliki istri lebih dari satu, selain itu istri-istri yang dikawininya pun bukan dari kalangan jandajanda yang lemah namun para wanita cantik yang masih muda. Disinilah terjadi penyelewengan makna dari poligami Nabi yang diadaptasi oleh banyak umat Islam pada saat ini.

Fenomena perkawinan sesama jenis, seperti transgender, transeksual, gay, lesbian, dan biseksual, merupakan bentuk deviasi sosial yang nyata terjadi dalam masyarakat. Perkawinan ini sangatlah jauh dari tujuan dan prinsip perkawinan sesungguhnya. Pada kenyataannya, perkawinan ini ditujukan untuk pemenuhan nafsu biologis semata dan menyimpang dari nilai, ajaran, dan norma-norma yang ada dalam agama, masyarakat, dan hukum yang telah ada. Selanjutnya, kawin misyar yang dikemukakan oleh Yusuf al-Qardawi memang tidak jauh beda dengan praktik sewa gigolo. Perkawinan ini tidak mengandung tujuan dan prinsip dari perkawinan, apalagi perkawinan ini dilakukan dengan sembunyisembunyi dan tidak untuk selamanya. Kawin misyar juga dapat menimbulkan masalah besar dalam masyarakat seperti fitnah. Sedangkan dalam agama Islam tidak pernah menganjurkan perkawinan yang hanya dapat menimbulkan mafsadat (kerusakan) untuk dilakukan.

\section{Penutup}

Tujuan ideal Islam dalam perkawinan adalah monogami. Tentang konsep poligami, yang jelas-jelas tertulis dalam Al-Qur'an hanyalah karena tuntutan zaman ketika masa Nabi, yang ketika itu banyak sekali anak yatim atau janda yang ditinggal bapak atau suaminya. Selain itu, kebolehan berpoligami hanyalah bersifat darurat atau kondisi terpaksa, sembari mengingatkan, agama adalah kesejahteraan (mashlahah) bagi pemeluknya. Sebaliknya, agama mencegah adanya dzarurat atau kesusahan. Dzarurat dikerjakan hanya kalau terpaksa. Dan dari kondisi ini, satu hal yang perlu dicatat, menolak kesusahan atau kemudharatan harus didahulukan daripada mendapatkan suatu kesejahteraan (kemashlahatan).

Perkawinan-perkawinan yang tidak sesuai dengan syariat Islam pun tidak pernah dibenarkan, seperti perkawinan sejenis (transgender, gay, lesbian, dan biseksual), kawin misyar, dan praktik poligami masa kini. Perkawinan merupakan suatu yang sangat tinggi nilainya dan memiliki tujuan-tujuan mulia ketika dilaksanakan. Perkawinan yang menyimpang 
dari tujuan mulia perkawinan akan menimbulkan banyak masalah dalam diri pelaku sendiri maupun masyarakat. Akibat dari perkawinan seperti ini antara lain munculnya keresahan dalam masyarakat, timbulnya fitnah, sanksi agama, sanksi sosial, juga sanksi hukum.

\section{Daftar Pustaka}

KHI

Undang-undang No 1 Tahun 1974 Tentang Perkawinan

Undang-undang Kesehatan dan Praktik Kedokteran

Abdurrahman, Kompilasi Hukum Islam Indonesia. Surabaya: Kesindo Utama, 2010.

Abu Shuja'. al-Iqna'. Surabaya: al-Hidayah, tt.

Afzalur Rahman. Ensiklopedi Nabi Muhammad Saw: Muhammad Sebagai Suami dan Ayah. Bandung: Pelangi Mizan, 2009.

Ali Yafie. Pandangan Islam Terhadap Kependudukan dan Keluarga Berencana. Jakarta: Lembaga Kemaslahatan Keluarga Nadhatul Ulama dan BKKBN, 1982.

Anshori Fahmi. Siapa Bilang Poligami itu Sunnah?. Bandung: Pustaka IIMaN, 2007.

Asghar Ali Engineer. Hak-hak Perempuan Dalam Islam. alih bahasa Farid Wajidi dan Cici Farika Assegaf, Yogyakarta: LSPPA 7 CUSO, 1994.

Beni Ahmad Syaebani. Perkawinan Hukum Islam \& Undang-Undang: Perspektif Fikih Munakahat \& Undang-Undang No. 1 tahun 1974 Tentang Poligami dan Problematikanya. Bandung: Pustaka Setia, 2008.

Didi Junaidi Ismail. Membina Rumah Tangga Islam di Bawah Rida Illahi. Bandung: Pustaka Setia, 2008.

Innayah Rohmaniyah. Menyoal Keadilan Dalam Poligami. Yogyakarta: PWS UIN Sunan Kalijaga, 2009.

Kamus Besar Bahasa Indonesia, edisi ke-2, Jakarta: Balai Pustaka.

Khairuddin Nasution. Riba \& Poligami: Sebuah Studi atas Pemikiran Muhammad Abduh. Yogyakarta : Pustaka Pelajar, 1996.

M. Quraish Shihab. Perempuan. Jakarta: Lentera Hati, 2005.

Nasiri. Praktik Prostitusi Gigolo ala Yusus al-Qardawi. Surabaya: Khalista, 2010.

Siti Musdah Mulia dan Anik Farida. Poligami: Budaya Bisu Yang Merendahkan Martabat Perempuan. Yogyakarta: Kibar Press, 2007.

Siti Syamsiatun dan Alimatul Qibtiyah. Amandemen Undang-Undang Perkawinan Sebagai Upaya perlindungan Hak Perempuan dan Anak. 
Yogyakarta: PSW UIN Sunan Kalijaga, 2006.

Tihami dan Sonari Sahrani, Fikih Munakahat. Jakarta: PT. Raja Grafindo Persada, 2010.

Wahbah al-Zuhaili. al-Figh al-Islami wa Adillatuh. Beirut: Dar al-Kutub, 1999.

http://mdakwatuna.com/fenomena transgender-dan-hukum-operasikelamin/

Solusi Masalah Psikologi, http://psikologi4u.blogspot.com/2008/08/transeksual-dan transgender, Diakses 6 April 2020.

Bangkitnya Gerakan Gay, Lesbian, Biseksual, dan Transgender Dunia, http://www.globalmuslim.web.id/2012/05/bangkitnya-gerakangay-lesbian.html, Diakses 7 Mei 2020. 